ONDERZOEK • VERSLAGGEVING - WET-EN REGELGEVING

\title{
US GAAP en de jaarverslag- geving van Nederlandse ondernemingen
}

Dr. R.G.A. Vergoossen en Drs. A.A.R. Polman

\section{Inleidling'}

Een aantal Nederlandse ondernemingen is genoteerd op effectenbeurzen in de Verenigde Staten. Uit dien hoofde moeten zij onder meer een jaarrapport deponeren bij de Securities and Exchange Commission (SEC) dat is opgesteld conform het zogenaamde Form 20-F. Hoewel de in het Form 20-F op te nemen jaarrekening in beginsel dient te voldoen atan Amerikatanse verslaggevingsregels (US Generally Accepted Accounting Principles; US GAAP), is hel ook mogelijk deze op te stellen conform Nederlandse verslaggevingsregels (NL GAAP).' In dat geval moeten afwijkingen mel US GAAP dic een aanmerkelijke invloed hebben op eigen vermogen en nettoresultaat worden gekwantificeerd. Dit kan geschieden in de vorm valn alansluitingsoverzichten (reconciliation statements).

Bestudering van de aansluitingsoverzichten geeft niet alleen inzicht in de verschillen tussen NL GAAP en US GAAP. maar ook in de effecten van deze verschillen op het gepresenteerde eigen vermogen en nettoresultaat. Vergoossen (1991) heeft in dat kader de jaarrapporten volgens Form $20-F$ van een achttal Nederlandse ondernemingen over het bockjaar 1990 onderzocht. In het buiten-

Dr. R.G.A. Vergoossen, registeraccountant, is universitair docent Bedrijfseconomie aan de Faculteit der Economische Wetenschappen en Econometrie van de Vrije Universiteit te Amsterdam. Tevens is hij werkzaam bij Moret Ernst \& Young te Rotterdam.

Drs. A.A.R. Polman studeert accountancy aan de Vrije Universiteit te Amsterdam. Hij is werkzaam bij Moret Ernst \& Young te Utrecht. land is gelijksoortig onderzoek verricht door onder anderen Weetman \& Gray (1990, 1991), Cooke (1993) en Hellman (1993). In de onderzoeken van Weetman \& Gray zijn ondernemingen uit het Verenigd Koninkrijk (1990, 1991), Zweden (1991) en Nederland (1991) betrokken.

Hel onderzoek van Cooke betreft Japanse ondernemingen en dat van Hellman heeft betrekking op Zweedse ondernemingen. Weetman \& Gray (1991) hestudeerden de Forms 20-F van zes Nederlandse ondernemingen over de bockjaren 1986, 1987 en 1988.

In hun artikel beperken zij zich evenwel tot een bespreking van de effecten van verschillen tussen NL GAAP en US GAAP op het nettoresultat van genoemde boekjaren. Er is niet specifiek ingegaan op de ontrikkeling in de tijd van de cijfermatige effecten van verschillen tussen NL GAAP en US GAAP.

In dit artikel worden allereerst kort de belangrijkste afwijkingen tussen NL GAAP en US GAAP besproken zoals die blijken uit de jaarrapporten volgens Form 2)-F over het boekjaar 1993. Daarna wordt nagegaan hoe de effecten op het eigen vermogen en het nettoresultaat van afwijkingen tussen NL GAAP en US GAAP zich in de afgelopen tien jaar hebben ontwikkeld en worden de ontwikkelingen geanalyseerd. Hierdoor kan onder meer inzicht worden verkregen in de mate waarin de betrokken Nederlandse ondernemingen bereid zijn zich te conformeren aan US GAAP. Dit artikel zou ook kunnen dienen als uitgangspunt voor beleggers en beleggingsanalisten die de cijfers van Nederlandse ondernemingen, die niet in de Verenigde Staten zijn genoteerd, willen vergelijken met de cijfers van ondernemingen die US GAAP toepassen. 


\section{Verschillen tussen NL GAAP en US GAAP}

In de Verenigde Staten worden de aandelen van in totaal 25 Nederlandse ondernemingen verhandeld. ${ }^{4}$ Dit geschiedt meestal in de vorm van American Depositary Receipts (ADR's). ${ }^{5} \mathrm{Het}$ jaarrapport volgens Form 20-F behoeft echter alleen te worden gedeponeerd door de ondernemingen waarvan in de Verenigde Staten tevens aandelennoteringen tot stand komen. In maart 1995 kwamen op de New York Stock Exchange of via het NASDAQ-systeem (National Association of Securities Dealers Automated Quotation System) aandelennoteringen tot stand van de navolgende Nederlandse ondernemingen: ${ }^{6}$

- Advanced Semiconductor Materials International NV,

- AEGON NV.

- Koninklijke Ahold NV,

- Akzo Nobel NV,

- ASM Lithography Holding NV.

- Elsevier NV,

- Heidemij NV,

- Koninklijke Luchtvaart Maatschappij NV,

- NV Koninklijke Nederlandsche Petroleum Maatschappij,

- Océ-van der Grinten NV,

- Philips Electronics NV,

- PolyGram NV en

- Unilever NV. ${ }^{7}$

ASM International, ASM Lithography en KNPM hebben zich bij de keuze van de verslaggevingsgrondslagen (onder andere) laten leiden door US GAAP, hetgeen impliceert dat de Forms
20-F van deze ondernemingen geen aansluitingsoverzichten met betrekking tot het eigen vermogen en nettoresultaat bevatten. In dit artikel blijven genoemde ondernemingen dan ook verder buiten beschouwing.

Onderstaande tabel is gebaseerd op de aansluitingsoverzichten zoals opgenomen in de jaarrapporten volgens Form 20-F over 1993 van de overige tien ondernemingen.

In tabel 1 is zowel in miljoenen guldens (c.q. ponden) als in procenten aangegeven welke invloed toepassing van US GAAP heeft op het eigen vermogen en nettoresultaat van genoemde ondernemingen. Toepassing van US GAAP heeft bij deze ondernemingen geleid tot een hoger eigen vermogen, variërend van 9 tot $94 \%$, en in de meeste gevallen tot een lager nettoresultaat, variërend van -75 tot $+1 \%$.

Bestudering van de aansluitingsoverzichten leert dat de aanpassingen onder meer betrekking hebben op de volgende zaken:

- de verwerkingswijze van goodwill,

- de waardering van immateriële vaste activa,

- de waardering van materiële vaste activa,

- de bepaling van de pensioenvoorziening en de pensioenkosten,

- de bepaling van de voorzieningen voor verzekeringsverplichtingen,

- de verwerkingswijze van dividenden.

Met uitzondering van Philips en PolyGram brengen alle in tabel 1 genoemde ondernemingen de betaalde goodwill rechtstreeks ten laste van het eigen vermogen, hetgeen volgens NL GAAP is geoorloofd. Volgens US GAAP echter moet de

Tabel 1: Eigen vermogen en nettoresultaat volgens NL GAAP en US GAAP (bedragen in miljoenen guldens c.q. ponden)

\begin{tabular}{|c|c|c|c|c|c|c|c|c|}
\hline \multirow[t]{2}{*}{$\begin{array}{l}\text { Naam } \\
\text { onderneming }\end{array}$} & \multicolumn{2}{|c|}{$\begin{array}{l}\text { Eigen vermogen } \\
\text { ultimo } 1993\end{array}$} & \multicolumn{2}{|c|}{$\begin{array}{l}\text { Effect } \\
\text { aanpassingen }\end{array}$} & \multicolumn{2}{|c|}{$\begin{array}{l}\text { Nettoresultaat } \\
\text { over } 1993\end{array}$} & \multicolumn{2}{|c|}{$\begin{array}{l}\text { Effect } \\
\text { aanpassingen }\end{array}$} \\
\hline & $N L G A A P$ & $U S G A A P$ & $i n f / f$ & $i n \%$ & $N L G A A P$ & $U S$ GAAP & in $f / f$ & in \% \\
\hline AEGON & 8.669 & 9.476 & +807 & +9 & 1.004 & 650 & -354 & -35 \\
\hline Ahold & 2.137 & 3.244 & +1.107 & +52 & 343 & 347 & - & +1 \\
\hline Akzo & 6.152 & 9.015 & +2.863 & +47 & 549 & 135 & $+\quad 414$ & -75 \\
\hline Elsevier & f 1.714 & $£ 2.420$ & $+£ 706$ & +41 & £ 396 & $£ 294$ & $-£ 102$ & -26 \\
\hline Heidemij & 143 & 234 & 91 & +64 & 19 & 17 & - & -7 \\
\hline KLM & 3.515 & 4.300 & $+\quad 785$ & +22 & 103 & 73 & 30 & -29 \\
\hline Ocē & 998 & 1.110 & $+\quad 112$ & +12 & 62 & 62 & 0 & 0 \\
\hline Philips & 11.449 & 12.683 & +1.234 & +11 & 1.965 & 1.663 & - 302 & -15 \\
\hline PolyGram & 2.023 & 2.929 & +906 & +45 & 614 & 534 & 80 & -13 \\
\hline Unilever & 13.504 & 26.263 & +12.759 & +94 & 3.612 & 2.676 & -936 & -26 \\
\hline
\end{tabular}


betaalde goodwill worden geactiveerd en afgeschreven over een periode van maximaal 40 jaar. Door Philips en PolyGram wordt de vanaf 1992 respectievelijk 1993 betaalde goodwill behandeld conform US GAAP, terwijl eerder betaalde goodwill rechtstreeks ten laste van het eigen vermogen is gebracht. Aanpassing aan US GAAP heeft in alle gevallen - dus (vooralsnog) ook bij Philips en PolyGram - een stijging van het eigen vermogen en een daling van het nettoresultaat tot gevolg.

In Nederland worden in toenemende mate door ondernemingen verworven immateriële vaste activa geactiveerd zonder dat deze systematisch worden afgeschreven. Volgens US GAAP is systematische afschrijving van alle immateriële vaste activa evenwel verplicht. Omdat PolyGram niet systematisch afschrijft op de geactiveerde muziekcatalogi leidt aanpassing aan US GAAP tot een daling van het eigen vermogen en nettoresultaat van zowel PolyGram zelf als moedermaatschappij Philips. Dit geldt eveneens voor Elsevier die uitgaverechten acliveert waarop in beginsel niet wordt afgeschreven.

In tegenstelling tot Nederland is in de Verenigde Staten waardering van materiële vaste activa tegen historische kosten verplicht. AEGON, Ahold, Elsevier, Heidemij en Océ hebben op dit punt in hun aansluitingsoverzichten aanpassingen opgenomen, omdat zij bepaalde categorieën materiële vaste activa waarderen tegen actuele waarde. Over het algemeen leidt een dergelijke aanpassing tot een daling van het eigen vermogen en een stijging van het nettoresultaat.

Bij de bepaling van de pensioenvoorziening en pensioenkosten zijn er tussen de Nederlandse verslaggevingspraktijk en US GAAP een aantal verschillen te onderkennen. Zo wordt in Nederland bij de berekeningen doorgaans uitgegalan van de huidige salarissen, terwijl in de Verenigde Staten rekening moet worden gehouden met toekomstige salarisontwikkelingen. Ook is er een verschil met betrekking tot de disconteringsvoet. In Nederland is een (lage) vaste rekenrente gebruikelijk. In de Verenigde Staten daarentegen wordt gerekend met een van de marktrente afgeleid percentage. $\mathrm{Bij}$ zes van de tien ondernemingen (Ahold, Akzo, Elsevier, Heidemij. KLM en Unilever) bevatten de aansluitingsoverzichten aanpassingen met uiteenlopende effecten op eigen vermogen en nettoresultaat. Voorzieningen voor verzekeringsverplichtingen hebben specifiek betrekking op AEGON. Deze voorzieningen, die mel name het levensverzekeringsbedrijf betreffen, worden bepaald door de contante waarde van de toekomstige uilkeringen te verminderen met de contante waarde van de nog te ontvangen premies. Doordat AEGON bij de bepaling van de voorzieningen rekenrenten en sterftetafels hanteert die afwijken van de volgens US GAAP te hanteren rekenrenten en sterftetafels, vinden aanpassingen plaats die leiden tol een hoger eigen vermogen en een lager nettoresultaat. In Nederland wordt het op balansdatum nog te declareren dividend doorgaans opgenomen onder de kortlopende schulden. In de Verenigde Staten dient het dividend echter onder het eigen vermogen te worden verantwoord tot het moment dat het dividend daadwerkelijk betaalbaar wordt gesteld. Ahold, Akzo, Elsevier, Heidemij. Philips en Unilever hebben op dit punt aanpassingen doorgevoerd. waardoor het eigen vermogen van deze ondernemingen toeneemt. Het nettoresultaat wordt uiteraard niet beïnvloed. KLM geeft expliciet aan dat een dergelijke aanpassing niet voor haar geldt, omdat over het boekjaar 1993 geen dividend wordt uitgekeerd. De aansluitingsoverzichten van AEGON, Océ en PolyGram bevatten geen aanpassingen met betrekking tot het nog te declareren dividend. Andere verschillen die tot expliciete aanpassingen hebben geleid. hebben onder meer betrekking op de behandeling van vreemde valuta's, de activering van interestkosten, de waardering van latente belastingverplichtingen en de verwerking van het cumulatief effect van stelselwijzigingen. ${ }^{8}$

\section{Ontwikkeling cijfermatige effecten van verschillen tussen NL GAAP en US GAAP"}

Hiervoor hebben we kort de verschillen besproken zoals die zich manifesteren in de aansluitingsoverzichten opgenomen in de jaarrapporten volgens Form 20-F over 1993. In het navolgende wordt voor iedere onderneming afzonderlijk nagegaan hoe de verschillen zich over een periode van tien jaar hebben ontwikkeld. Eerst komen de ondernemingen aan de orde die gedurende de gehele onderzoeksperiode jaarrapporten volgens Form 20-F hebben gedeponeerd en daarna de ondernemingen waarbij dat niet het geval is. Elsevier en Heidemij blijven evenwel verder buiten beschouwing, ondat deze ondernemingen pas sinds kort een jaarrapport volgens Form 20-F deponeren bij de SEC. 
Door middel vall grafieken word de ontwikkeling van de procentuele verschillen tussen het eigen vermogen en het netroresultal volgens NL GAAP en US GAAP over de boekjaren 1984101 en met 1993 anngegeven. " De procentuele verschillen voor wall betreft het cigen vermogen zijn als volgu berekend:

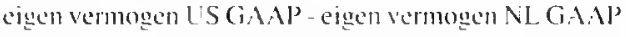

$$
\text { kigen vermogen NL (iA AP }
$$

Aldus geven de percentiages alan met hoeveel procent het eigen vermogen volgens NL GAAP zou stijgen of dalen indien US GAAP words toegepast. Voor het nettoresultalat geldt een overeenkomslige berekening.

\section{$A E G O N N \mid$}

In liguur I geeft de lijngrafiek de ontwikkeling valn het procentuele verschil tussen het eigen vermogen volgens NL GAAP en US GAAP weer en het stiafdiagram de ontwikkeling van het procentuele verschil tussen het nettoresultaat volgens NL GAAP en US GAAP.

Uit liggur I komt naar voren dat er vanal 1987 sprake is van een daling van het verschil mel betrekhing tol hel eigen vermogen. Afgezien van $1988 \mathrm{en} 1993$ is bij het netoresultat eenzellde verloop watar te nemen. De afwijking in 1988 houdı onder meer verband mel een énmalige belastinglast met betrekking tol de egalisatiereserve. Deze post is door AEGON direct verwerkt in het cigen vermogen, terwijl die volgens US GAAP in de winst-en verliesrekening had moeten worden verantwoord. Het grote verschil tussen het nettoresultiat over 1993 volgens NL GAAP en dill volgens US GAAP word mel name veroorzalikl

Figmur I: Omwikkeling verschillen AEGON

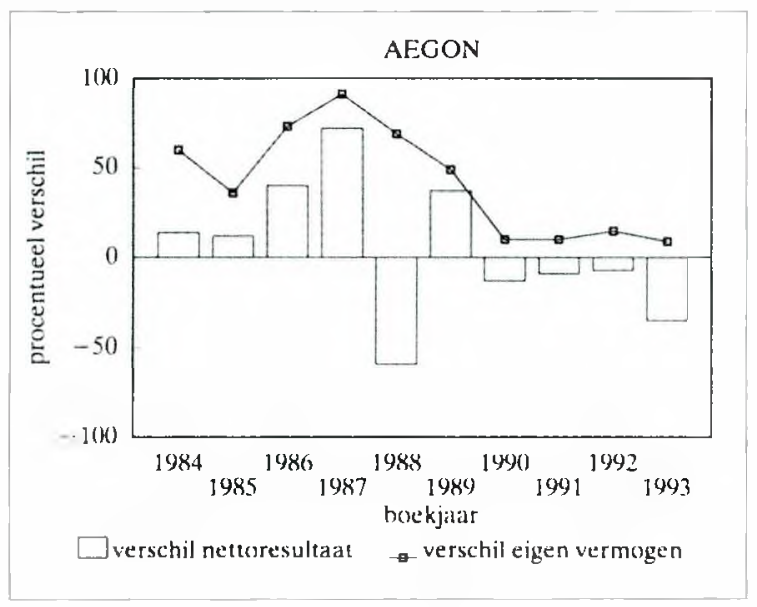

door een wijziging in de berekening van belastingen in verband met de introductie van Stallement of Financial Accounting Standards No. 109 (SFAS 109). 'Accounting for income' taves". Het cumulatieve effect van deze wijziging op voorgalande jaren moest ten laste van de winst- en verliesrekening worden gebracht. In de jaarrekening van AEGON opgesteld conform NL GAAP is van een dergelijk effect evenwel geen sprake, omdat de volgens SFAS 109 verplichte toepassing van de zogenatamde liability methode in deze jatarrekening reeds werd locgepast.

De daling van de verschillen in de loop van de lijd word met name veroorzaakit door het steeds meer loepassen valn waarderings- en resultaatbepalingsgrondsligen die (meer) overeenstemmen met US GAAP. Vooral in 1990), matar ook in 1985. 1986 en 1993 zijn door AEGON stelselwijzigingen in die richting doorgevoerd. De stelselwijzigingen doorgevoerd in 1990) hebben onder meer betrekking op de behatndeling van de kosten die variëren met en direct gekoppeld zijn atan de produktie valn verzekeringen (de zogenalamde eerste kostenl en de verant woording van de verkoopresultaten op beleggingen in aandelen en onroerend goed. De eersic kosten worken niet meer ineens in het jaar van ats sluiten. matar gespreid over de periode van de premie-ontvangst ten laste van het resultat gehracht. De verkoopresultaten op beleggingen in aandelen en onroerend goed worden niet meer rechtstreeks in het eigen vermogen verwerkt. malar ten gunste of ten laste van de winst-en verliesrekening gebracht."

De aanpassingen alan US GAAP die eigen vermogen en nettoresultaat valn AEGON gedurende de gehele onderzoeksperiode (1984-1993) in belangrijke mate beïnvloeden. betreffen de verwerkingswijze van goodwill, de waardering van materiële vaste activa en de bepaling van de voorziening voor verzekeringsverplichtingen. Verder kian hel nettoresultiat sterk worden beinnvloed door ainpassingen met betrekking tot gerealiseerde winsten op vastrentende watarden. Deze winsten worden door AEGON in de resterende looptijd ten gunste van de winst-en verliesretening gebracht. terwijl die volgens US GAAP in één keer in de winst- en verliesrekening moeten worden verwerkt. Ondat de gerealiseerde winsten op vastrentende walarden naar hun aard grote schommelingen vertonen. kunnen de alanpassingen die moten worden verantwoord in de alansluitingsoverzichten in de loop der jaren aanmerkelijk variëren. 


\section{Koninklijke Luchtraart Maatschappij NV}

Het procentuele verschil tussen het eigen vermogen van KLM volgens NL GAAP en US GAAP is - met uitzondering van 1993 - klein te noemen. Voor wat betreft het nettoresultaat is er in 1993 na een drietal jaren met relatief kleine verschillen weer sprake van een verschil van ongeveer $29 \%$.

De relatief grote verschillen in 1993 worden veroorzaakt doordat KLM (pas) met ingang van 1993 de effecten op het eigen vermogen en het nettoresultaat kwantificeert als gevolg van de toepassing van verslaggevingsgrondslagen die afwijken van SFAS 87, 'Employers' Accounting for Pensions'. In de Forms 20-F over eerdere jaren heeft KLM deze kwantificeringen achterwege gelaten.

Het verschil van $17 \%$ in 1989 tussen het nettoresultaat volgens NL GAAP en US GAAP is het gevolg van de éénmalige effecten van twee stelselwijzigingen die hebben geleid tot de toepassing van US GAAP. Zo zijn de koersverschillen op langlopende schulden en financiële vaste activa met ingang van 1989 in het jaar van ontstaan in de winst- en verliesrekening verwerkt. hetgeen volgens US GAAP verplicht is, en niet meer - in geval van een per balansdatum positief saldo synchroon met de aflossingen van de betrokken posten. Naar aanleiding van deze stelselwijziging is het saldo van de koersverschillenrekening door KLM verantwoord als buitengewone bate. Ter bepaling van het nettoresultaat volgens US GAAP is deze bate evenwel geëlimineerd. omdat die volgens US GAAP al eerder als resultaat had moeten worden verantwoord. De van US GAAP

Figuur 2: Ontwikkeling verschillen KLM

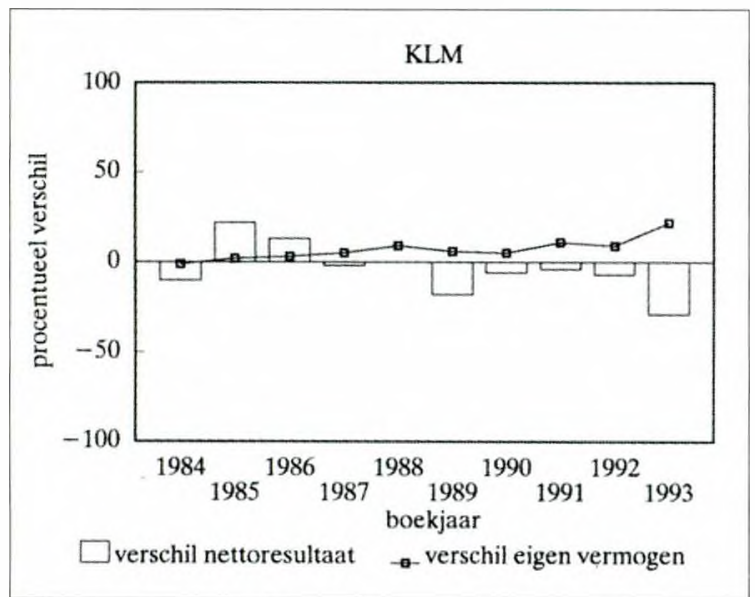

afwijkende behandeling van onderhavige koersverschillen vóór 1989 veroorzaakte overigens de fluctuerende verschillen tussen het nettoresultaat volgens NL GAAP en dat volgens US GAAP.

Als gevolg van de in 1989 doorgevoerde stelselwijzigingen werd het aantal materiële afwijkingen gereduceerd tot één, namelijk die met betrekking tot goodwill. In het Form $20-\mathrm{F}$ over 1993 bevatten de aansluitingsoverzichten echter ook aanpassingen met betrekking tot pensioenen (zoals hiervoor reeds besproken) en met betrekking tot nog te declareren dividenden. KLM heeft inmiddels besloten om met ingang van het boekjaar 1994 een stelselwijziging met betrekking tot goodwill door te voeren. KLM vermeldt daarover onder meer het volgende: "De bij verkrijging van deelnemingen betaalde goodwill zal - in overeenstemming met een sterker wordende internationale trend - worden geactiveerd en afgeschreven. Hiermee wordt ook voldaan aan de Amerikaanse voorschriften. ... De tot en met 31 maart 1994 rechtstreeks ten laste van het eigen vermogen afgeboekte goodwill wordt niet alsnog geactiveerd."12 In navolging van Philips en PolyGram zet ook KLM haar eerste schreden in de richting van de behandeling van goodwill a la US GAAP. De aansluitingsoverzichten in toekomstige Forms 20-F zullen waarschijnlijk toch nog aanpassingen bevatten met betrekking tot goodwill, omdat de stelselwijziging zonder terugwerkende kracht wordt doorgevoerd.

\section{Océ-van der Grinten NV}

De belangrijkste aanpassingen in de Forms 20$F$ van Océ betreffen de verwerking van goodwill en de waardering van materiële vaste activa. De

Figuur 3: Ontwikkeling verschillen Océ

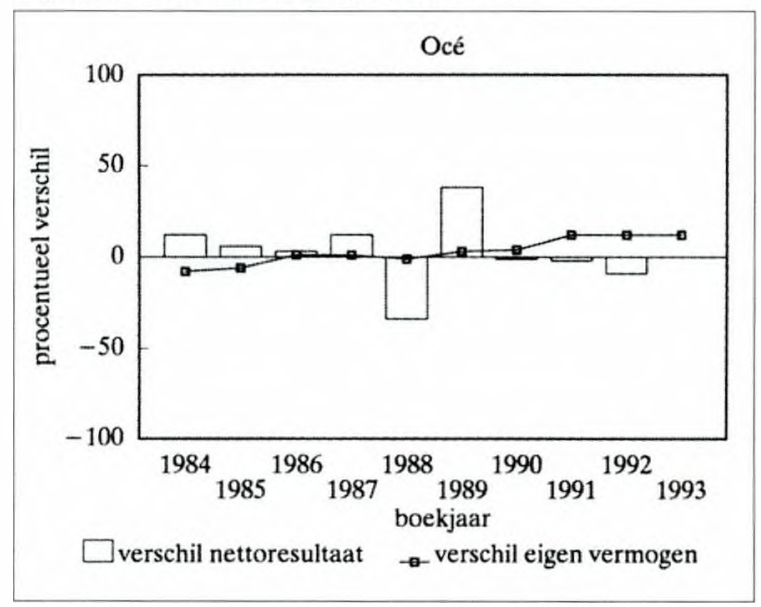


gezamenlijke invloed van deze twee aanpassingen op het eigen vermogen en nettoresultaat is evenwel relatief gering, doordat de effecten van de aanpassingen elkaar voor een groot deel compenseren.

De grote verschillen tussen het nettoresultaat volgens NL GAAP en US GAAP in de jaren 1988 en 1989 houden verband met het afstoten van deelnemingen. In 1988 betreft het omrekeningsverschillen met betrekking tot een buitenlandse deelneming die in voorgaande jaren direct in het eigen vermogen zijn verwerkt. Volgens US GAAP moeten dergelijke verschillen bij de verkoop van buitenlandse deelnemingen alsnog in de winst-en verliesrekening worden verantwoord. In 1989 is de bij de verkoop van een deelneming gerealiseerde goodwill rechtstreeks aan het eigen vermogen toegevoegd, terwijl dat volgens US GAAP via de winst- en verliesrekening had moeten geschieden.

\section{Philips Electronics NV}

Figuur 4 geeft de ontwikkeling van de verschillen met betrekking tot Philips weer. In de onderzoeksperiode heeft toepassing van US GAAP in de eerste zeven jaar geleid tot een lager eigen vermogen en in de laatste drie jaar tot een hoger eigen vermogen. Het nettoresultaat volgens US GAAP is vrijwel steeds lager dan het nettoresultaat volgens NL GAAP.

De belangrijkste aanpassingen hebben betrekking op de verwerking van goodwill en de walardering van materiële activa. Vooral de effecten van eerstgenoemde aanpassing - een hoger eigen vermogen en een lager nettoresultaat - zijn gedurende de onderzoeksperiode sterk in belang toegenomen. Het bijzonder grote verschil in 1992

Figuur 4: Ontwikkeling verschillen Philips

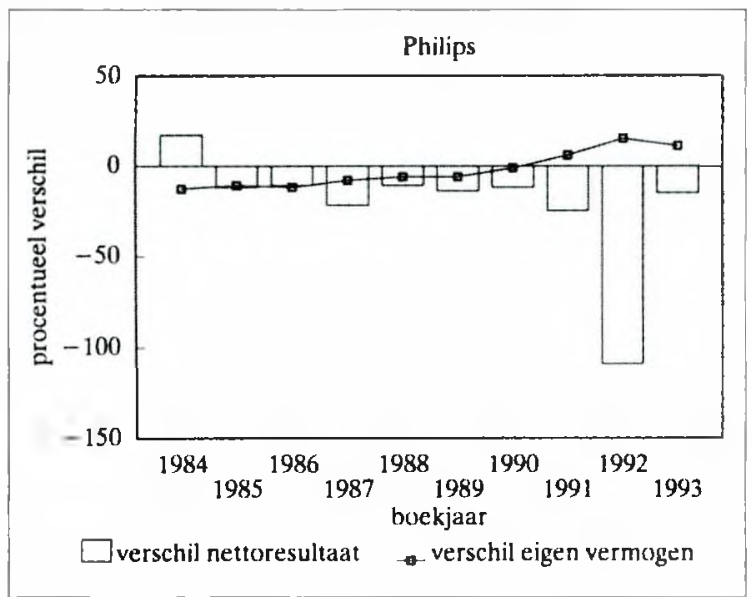

met betrekking tot het nettoresultaat (-109\%) is met name het gevolg van een (éénmalige) extra afboeking van betaalde goodwill vanwege een structurele walardedaling. De desbetreffende goodwill, die vóór 1992 is betalald, heeft Philips rechtstreeks ten laste van het eigen vermogen gebracht. Volgens US GAAP echter had die indertijd moeten worden geactiveerd en in 1992 ten laste van het resultaat moeten worden afgeboekt.

In 1992 en 1989 heeft Philips een aantal belangrijke stelselwijzigingen doorgevoerd die hebben geleid tot het toepassen van waarderingsen resultaatbepalingsgrondslagen die meer in overeenstemming zijn met US GAAP. In 1992 betreft het de navolgende stelselwijzigingen:

- vervanging van een actuele waardestelsel door een historische kostenstelsel:

- vervanging van de lokale munteenheid door de US dollar als functionele valuta voor hyperinflatielanden ${ }^{13}$;

- het activeren en afschrijven over een periode van maximaal 40 jaar van goodwill ontstaan bij verwerving van deelnemingen vanaf 1992. In voorgaande jaren is goodwill rechtstreeks ten laste van het eigen vermogen gebracht;

- het activeren en afschrijven over een periode van maximaal 3 jaar van bepaalde uitgaven voor software-ontwikkeling wanneer vaststaat dat de desbetreffende softwareprodukten over een langere periode verhandelbaar zijn. Naast deze stelselwijzigingen maakt Philips melding van het feit dat met ingang van 1993 SFAS 106, 'Employers' Accounting for Postretirement Benefits Other Than Pensions', zal worden toegepast. De stelselwijziging met betrekking tot goodwill is niet met terugwerkende kracht doorgevoerd. hetgeen betekent dat de aansluitingsoverzichten in toekomstige Forms $20-\mathrm{F}$ van Philips nog steeds goodwill-aanpassingen zullen bevatten. Naarmate de tijd voortschrijdt zullen deze aanpassingen echter kleiner worden.

In tegenstelling tot de in 1992 doorgevoerde stelselwijzigingen hebben de in 1989 doorgevoerde stelselwijzigingen niet geleid tot een zichtbare verkleining van de verschillen tussen eigen vermogen en nettoresultaat volgens NL GAAP en US GAAP. Deze stelselwijzigingen hadden onder meer betrekking op de berekening van kosten van pensioenregelingen en de financieringscorrectie in landen met hyperinflatie. Voor wat betreft de berekening van kosten van pensioenregelingen 
basecrl Philips zich met ingang valn 1989 mede op SFAS 87, 'Emplovers' Accomnting for Pensions'. De ansluitingsoverzichlen opgenomen in de Forms 20-F van vór 1989 bevalten evenwel geen aampassingen in verband met alfwijkingen van SFAS 87. De wijziging met betrekking tot de financieringscorrectic in landen mel hyperinllatic betrof ecn verfijning van hel door Philips gelanteerde actuele wardestelsel.

\section{Unilerer NI}

Toepassing van US GAAP heefi bij Unilever vooral invloed op het eigen vermogen. In de I weede helft van de onderzoeksperiode leidl dal zelts tol stijgingen van meer dan $10(1 \% \%$. Bij Unilever is de verwerking van goodwill verreweg de belangrijkste anpassing. Andere belangrijke aampassingen hebben betrekking op de aclivering van interestkosten en nog te declareren dividenden. Vergekeken met het eigen vermogen is de invloed van toepassing van US GAAP op hel nettoresulaal relatief beperkt. Afgezien van enkele incidentele aanpassingen, worden de verschillen voornamelijk veroorzalakt door de afwijkende verwerking van betalale goodwill.

De relatief grote verschillen tussen het nettoresultaal volgens NL GAAP en US GAAP in 1987 $(+17 \%)$ en $1993(-26 \%)$ zijn hel gevolg van cumulatieve ellecten van stelselwijzigingen die in de desbetreffende jaren zijn doorgevoerd. Volgens US GAAP moeten dergelijke effecten (doorgaans) worden verantwoord in de winst-en verliesrekening, terwijl Unilever dic direct in hel eigen vermogen heelt verwerkt. In 1987 batreft het een wijziging van de alschrijvingsmethode ten alanzien van malleriële vaste activa en in 1993 een wijzi-

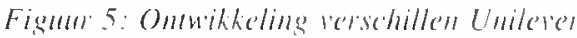

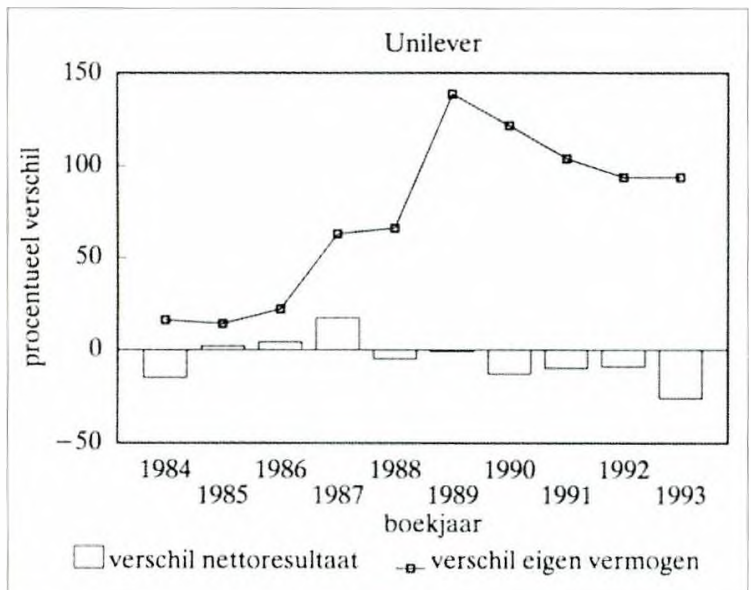

ging in verband met de introductie van SFAS 106. 'Emplovers' Accounting for Postretirement Bencefits Other Than Pensions'. Contorm SFAS 106 brengt Unilever de vergoedingen voor gezondheidszorg aan gepensioneerde werknemers niet meer ten laste van de winst-en verliesrekening in het jaar waarin zij verschuldigd ziju. maar treli hiervoor stelselmatig een voorziening zodal de vergoedingen ten laste van de winst- en verliesrekening worden gebracht tijdens de dienstjaren van de desbetreffende werknemers. Verder wordt het nettoresullatat van Unilever over 1993 (positief) beïnvloed door hel éénmalige effect van een wijziging in de berekening van belastingen in verband met de introductie van SFAS 109. In de jaarrekening van Unilever opgested conform NL GAAP is van een dergelijk eflect evenwel geen sprake, ondat de volgens SFAS 109 verplichte tocpassing van de zogenaamde liability methode in deze jatarrekening reeds werd toegepast (zie ook AEGON).

In 1990 en 1991 heefi Unilever nog stelselwijzigingen doorgevoerd met betrekking lot de hehandeling van vreemde valuta's. Deze stelselwijzigingen hebben geleid lot de toepassing van grondslagen die (meer) in overeenstemming zijn met US GAAP. Zo worden met ingang van hel boekjaar 1990 bij de opstelling van de geconsolidecrde jaarrekening in guldens de winst - en verliesrekeningen van groepsmaatschappijen luidende in vreende valuta's niet meer tegen cindkoersen maar tegen gemiddelde koersen omgerekend, hetgeen in overeenstemming is met SFAS 52, "Foreign Currency Translation'.

\section{Koninklijke Ahold NV}

Ahold is sinds 1991 genoteerd in de Verenigde Staten. Het eerste Form 20-F dal Ahold bij de SEC deponeerde, betrof het bockjalar 1989. ${ }^{4} \mathrm{De}$ in figuu 6 weergegeven ontwikkelingen betreffen de periode 1988-1993. walarbij de verschillen met betrekking 1ot 1988 zijn ontleend aan de vergelijkende cijfers opgenomen in het Form 20-F over 1989.

Ook bij Ahold is voor wal betreft het eigen vermogen de goodwill-alanpassing verreweg de belangrijkste. Deze ampassing is sedert 1988 vervijtvoudigd. In de loop van de lijd heefl ook de loepassing van SFAS 87. 'Employers' Accounling for Pensions'. een toenemende (positicve) invloed op het eigen vermogen. Een andere materiële anpassing met een negatieve invloed op 


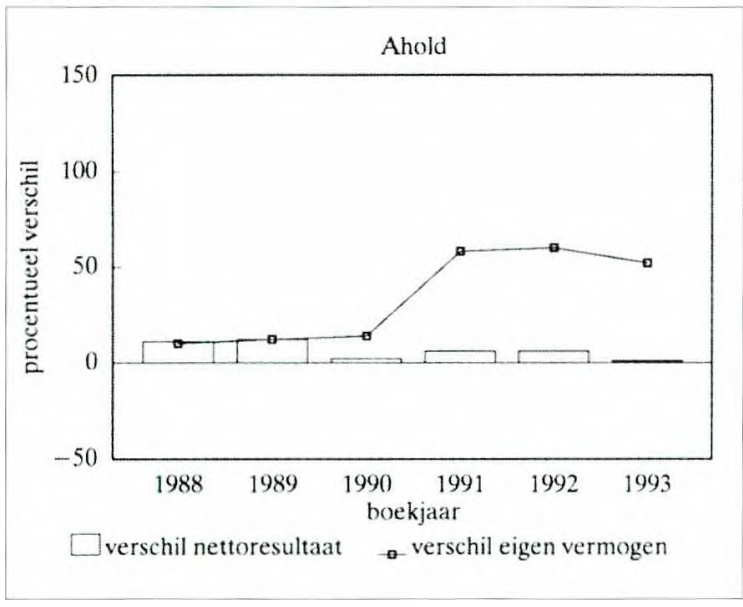

het eigen vermogen heefi betrekking op de wallrdering van malleriële vaste activa.

De effecten van de aanpassingen op het nettoresultail zijn per saldo relatief beperkt. Niast de hiervoor genoemde ainpassingen bevatten de annslutingsoverzichten met betrekking tot het nettoresultala cen alanpassing op grond van SFAS 52. 'Foreign Currency Translation'. Deze alanpassing heeft botrekking op wisselkoersverschillen die Ahold rechtstreeks in hel cigen vermogen heeli verwerkt, lerwijl volgens US GAAP verantwoording in de winst- en verliesrekening had moeten plaatsvinden. De aanpassing op grond van SFAS 52 heeft in sommige jaren een positief en in andere jaren een negatief elfect op het nettoresultait. De relatief grote verschillen in $1988 \mathrm{en} 1989$ zijn in belangrijke mate hel gevolg valn bockwinsten bij de verkoop valn deelnemingen die Ahold rechtstrecks ten gunste van het eigen vermogen heefi gebracht. Volgens US GAAP hadden die in de winst- en verliesrekening moeten worden verwerkt.

\section{$A k=0 \mathrm{Nobe} N \mathrm{NI}$}

Sinds 1989 is Akzo in de Verenigde Staten genoteerd. Het cerste Form 20-F dat Akzo bij de SEC deponeerde. betrof het boekjaar 1987 en de eerste negen maknden van het boek jaar 1988. Figuur 7 geefi de ont wikkelingen over de periode 1987-1993 weer. De verschillen met betrekking tor 1987 zijn ontleend aan de vergelijkende cijfers opgenomen in het hiervoor genoemde Form 20-F.

Bij Akzo is in de loop van de tijd sprake van een vrij stabiel verschil tussen het eigen vermogen volgens NL GAAP en US GAAP. Dit verschil wordt voornamelijk veroorzakkt door de goodwill-
Figun 7: Onwikkeling rerschillen Ak=0

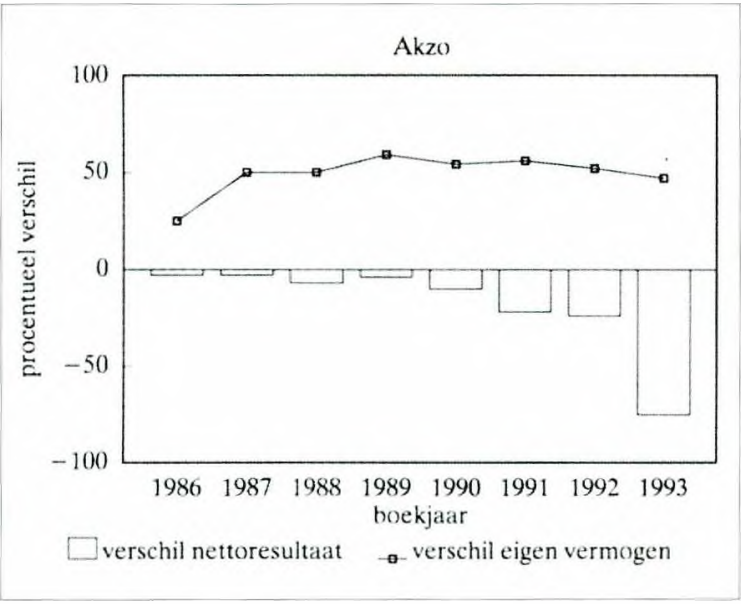

aampassing. Daamalast is er nog een aanpassing met betrekking tot de verwerking van nog te declareren dividenden. Ook hel verschil lussen hel nettoresultalt volgens NL GAAP en US GAAP is tot en met 1990 voornamelijk het gevolg van de goodwill-aanpassing. Belangrijke aanpassingen ten aamzien van het nettoresultalat in latere jaren lebben belrekking op de toepassing van SFAS 87. 'Employers' Accommting for Pensioms', en de verantwoording van volgens US GAAP nietalgeschreven goodwill bij de verkoop van deelnemingen. Het zal duidelijk zijn dat laatstgenoende aampassing verband houd met het rechtstreeks icn laste van het eigen vermogen brengen van betaalde goodwill.

Zoals uit figuur 7 blijkt, wijkl het nettoresullatat over 1993 volgens NL GAAP in belangrijke mate af van dat volgens US GAAP. Deze afwijking word voor een grool deel veroorzaakl door SFAS 106. 'Employers' Accoumting for Postretireme'm Benefits Othe' Than Pensions', walrmee bij de berekening van het nettoresultaat volgens US GAAP in 1993 voor het eerst rekening is gehouden. Naast het negatieve effect op het nelloresultalat dal in 1993 voornamelijk een éémmalig inhalalefiect betreft, heeft toepassing van SFAS 106 eveneens een negallief clfect op het eigen vermogen. In tegenstelling tor bijvoorbeeld Philips en Unilever heeft Akzo haar eigen verslaggevingsgrondslagen (nog) niet aangepast aan SFAS 106.

\section{Polliom NI'}

PolyGram is sinds 1989 in de Verenigde Staten genotecrd. In fïgur 8 ziju de ontwikkelingen over de periode 1988 - 1993 weergegeven. walabij de verschillen met betrekking tot 1988 


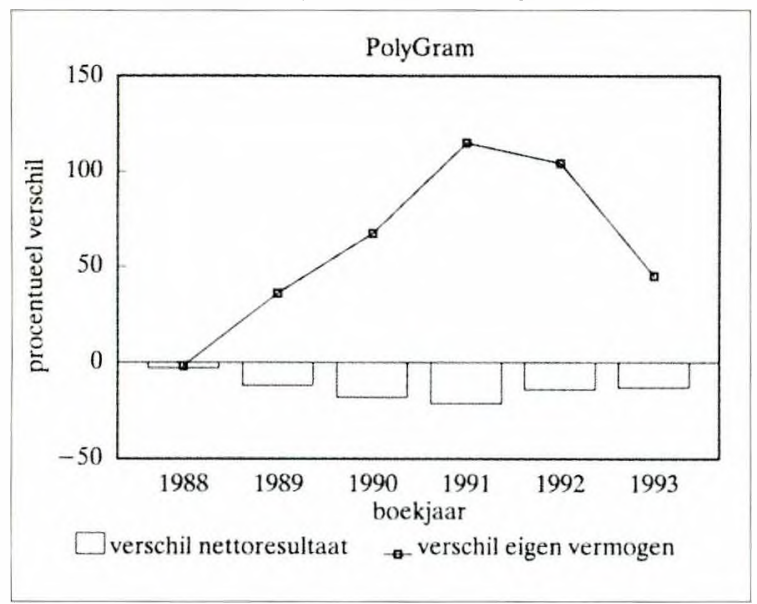

zijn ontleend aan de vergelijkende cijfers opgenomen in het Form 20-F van PolyGram over 1989.

Het verloop van de verschillen, zowel met betrekking tol het eigen vermogen als het nettoresultaat, wordt met name bepalald door de goodwill-aanpassing en de aanpassing van de verwerking van geactiveerde muziekcatalogi. PolyGram schrijft de geactiveerde muziekcatalogi alleen at indien en voor zover de indirecte opbrengstwaarde daalt beneden de boekwaarde. Volgens US GAAP echter moeten alle immateriële vaste activa op systematische wijze worden afgeschreven.

PolyGram heeft in 1993 een stelselwijziging doorgevoerd met betrekking tot de verwerking van goodwill. Voortaan wordt de betaalde goodwill niet meer rechtstreeks ten laste van het eigen vermogen gebracht. maar geactiveerd en afgeschreven over een periode van maximaal 40 jaar. Evenals bij moedermaatschappij Philips is deze stelselwijziging niet met terugwerkende kracht doorgevoerd. Daarnaast heeft Polygram in 1993 een stelselwijziging doorgevoerd in verband met het van kracht worden van SFAS 106 in de Verenigde Staten.

\section{Evaluatie}

Het is evident dat de toepassing van US GAAP een grote invloed kan hebben op de door ondernemingen gepresenteerde cijfers. In de tweede helft van de onderzoeksperiode (1989-1993) leidde loepassing van US GAAP door de betrokken ondernemingen meestal tot een hoger eigen vermogen en een lager nettoresultaat. In de eerste helft van de onderzoeksperiode (1984-1988) is er sprake van een minder eenduidig beeld. Een en ander hangt samen met de aanpassingen naar
Figun! 9: Gomiddeld verschil eigen vermogen. inc/usief en exclusief goodwill-aanpassing

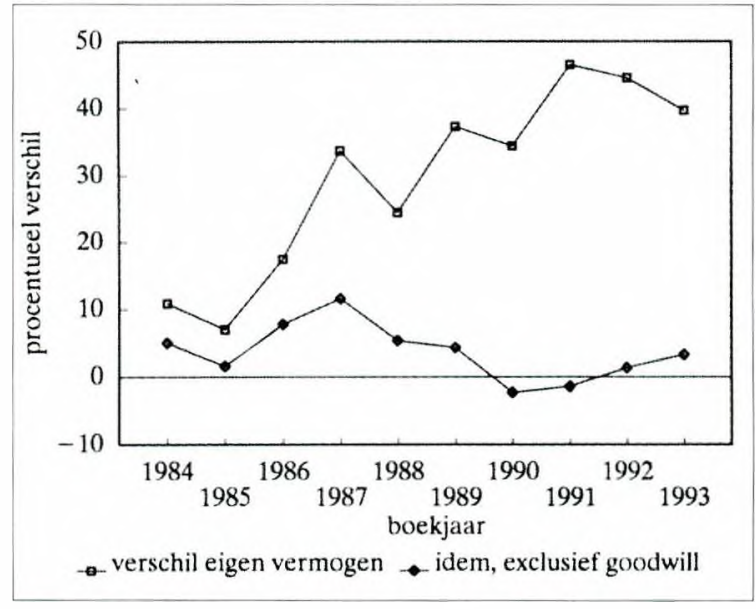

aanleiding van de afwijkende behandeling van betaalde goodwill, die met name de laatste jaren in steeds grotere mate het eigen vermogen positief en het nettoresultaat negatief hebben beïnvloed. Dit blijkt duidelijk uit figuur 9 voor wat betreft het eigen vermogen en figuur 10 voor wat betreft het nettoresultaat. In deze figuren is aangegeven met hoeveel procent de gepresenteerde cijfers van de onderzochte ondernemingen in de loop der jaren gemiddeld zijn gestegen of gedaald door aanpassing aan US GAAP, zowel inclusief als exclusief de goodwill-aanpassing.

Figuur 9 laat zien dat eliminatie van de goodwill-aanpassing leidt tot een afvlakking van het gemiddeld procentueel verschil tussen het eigen vermogen volgens NL GAAP en US GAAP; vóór eliminatic beweegt het verschil zich tussen 7 en $47 \%$ en na eliminatie tussen -3 en $+12 \%$. Van een dergelijke afvlakking is bij het nettoresultaat veel minder sprake; uit figuur 10 kan worden afgelezen dat vóór eliminatie van de goodwill-aanpassing

Figur 10: Gemiddeld rerschil nettoresuliaul, inclusief en exclusief goodwill-aanpassing

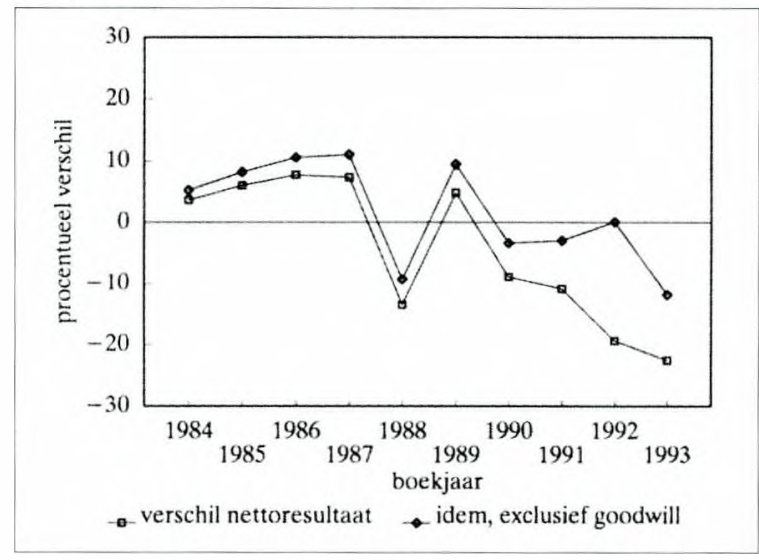


het verschil varieert tussen -23 en $+8 \%$ en na eliminatie tussen -12 en $+11 \%$. Een en ander kan worden verklaard door incidentele aanpassingen die bij de onderzochte ondernemingen vaak grote uitschieters in de verschillen tussen het nettoresultaat volgens NL GAAP en US GAAP veroorzaken, bijvoorbeeld éénmalige effecten als gevolg van stelselwijzigingen of resultaten bij het afstoten van deelnemingen. De invloed van de resterende aanpassingen aan US GAAP op het nettoresultaat kan over het algemeen als vrij beperkt worden gekwalificeerd.

Bij de onderzochte ondernemingen valt een duidelijk jaarrekeningbeleid te onderkennen in de richting van het steeds meer toepassen van grondslagen die overeenstemmen met US GAAP. Een dergelijk jaarrekeningbeleid wordt mogelijk gemaakt door het globale karakter en de daaruit voortvloeiende flexibiliteit van NL GAAP. Hoewel er bij veel ondernemingen stelselwijzigingen zijn doorgevoerd die zijn geïnitieerd door internationale ontwikkelingen, lijkt het erop dat men alleen daartoe bereid is indien de gepresenteerde cijfers daardoor niet al te negatief worden benvloed. Dat van een dergelijke terughoudendheid sprake is, blijkı uit de wijziging van de behandeling van betaalde goodwill door KLM, Philips en PolyGram. Het nieuwe stelsel - activeren en afschrijven - wordt uitsluitend toegepast met betrekking tot 'nieuwe goodwill'. Met andere woorden, het nieuwe stelsel wordt niet met terugwerkende kracht doorgevoerd. Hierdoor wordt voorkomen dat eerder betaalde goodwill, die rechtstreeks ten laste van het eigen vermogen is gebracht, alsnog een drukkend effect heeft op toekomstige winstcijfers. ${ }^{16}$

Tegenover de afname van de verschillen tussen het eigen vermogen en het nettoresultaat volgens NL GAAP en US GAAP als gevolg van stelselwijzigingen, staat in sommige gevallen een toename als gevolg van de introductie van nieuwe SFAS's, bijvoorbeeld Akzo met betrekking tot SFAS 106, 'Employers' Accounting for Postretirement Benefits Other Than Pensions' en KLM met betrekking tot SFAS 87, 'Employers' Accounting for Pensions'.$^{17}$ Andere ondernemingen passen daarentegen direct de nieuwe SFAS's toe, bijvoorbeeld Philips en Unilever ten aanzien van SFAS 106.

Door de flexibiliteit van NL GAAP is het niet goed mogelijk om vuistregels te geven voor de aanpassing aan US GAAP van een jaarrekening opgesteld volgens NL GAAP. Zoals uit het voorgaande is gebleken. zullen beleggers en beleggingsanalisten die Nederlandse ondernemingen, die niet aan een Amerikaanse beurs zijn genoteerd, willen vergelijken met ondernemingen die US GAAP toepassen, in elk geval rekening moeten houden met de volgende zaken:

- het eigen vermogen en de rentabiliteitscijfers van Nederlandse ondernemingen kunnen belangrijk afwijken door het rechtstreeks ten laste van het eigen vermogen brengen van betaalde goodwill:

- de door Nederlandse ondernemingen gepresenteerde winstcijfers kunnen belangrijk verschillen doordat incidentele resultaten rechtstreeks in het eigen vermogen zijn verwerkt;

- de introductie van nieuwe SFAS's kunnen een belangrijk stempel drukken op de winstcijfers van ondernemingen die US GAAP toepassen. Naast deze min of meer algemeen geldende zaken moet rekening worden gehouden met zaken die specifiek gelden voor een bepaalde bedrijfstak. zoals de van US GAAP afwijkende waardering van uitgaverechten in de uitgeversbranche en de van US GAAP afwijkende waardering van onroerend goed en voorzieningen voor verzekeringsverplichtingen in de verzekeringsbranche.

\section{I T E R A T U U R}

Cooke T.E., (1993), The Impact of Accounting Principles on Profits: The US versus Japan, Accounting and Business Research, najaar.

Hellman N., (1993), A Comparative analysis of the Impact of Accounting Differences on Profits and Return on Equity: Differences between Swedish Practice and US GAAP, European Accounting Review, 3.

Link A.J., (1995), Een andere kijk op zaken, De Accountant, maart.

Moliterno S.F. (red.), (1991), The Accounting Profession in the Netherlands, tweede herziene druk, American Institute of Certified Public Accountants, New York.

Vergoossen R.G.A., (1991), Rapportering 'on Form 20-F': Effecten van verschillen tussen Nederlandse en Amerikaanse verslaggevingsgrondslagen, Maandblad voor Accountancy en Bedriffseconomie, oktober.

Weetman P. \& Gray S.J., (1990), International Financial Analysis and Comparative Corporate Performance: The Impact of UK versus US Accounting Principles on Earnings, 
Journal of International Financial Management and

Accounting, 2 \& 3

Weetman P. \& Gray S.J., (1991), A Comparative International Analysis of the Impact of Accounting Principles on Profits: The USA versus the UK, Sweden and The Netherlands, Accounting and Business Research, najaar.

\section{NOTE N}

1 De heren Prof. Dr. M.N. Hoogendoorn, Prof. Dr. J. Klaassen en Prof. Dr. L.G. van der Tas danken wij voor hun commentaar op de concept-versie van dit artikel.

2 Gemakshalve worden de Nederlandse verslaggevingsregels in het vervolg van dit artikel aangeduid als NL GAAP. Op de keper beschouwd is dit niet geheel juist, omdat in Nederland niet wordt gesproken van 'aanvaarde grondslagen' zoals in de Verenigde Staten, maar van 'aanvaardbare grondslagen'.

3 Naast verschillen in waarderings- en resultaatbepalingsgrondslagen bestaan er tussen Nederland en de Verenigde Staten verschillen op het gebied van in de toelichting of het bestuursverslag te verstrekken (additionele) informatie.

Laatstgenoemde verschillen zijn in dit artikel niet aan de orde. Link (1995) besteedt wel aandacht aan deze verschillen.

4 Zie Het Financieele Dagblad d.d. 17 maart 1995.

5 Een ADR is een bewijs dat aandelen van niet-Amerikaanse ondernemingen vertegenwoordigt die zijn gedeponeerd bij een Amerikaanse bank.

6 Zie noot 4.

$7 \mathrm{KLM}$ en Océ hebben gebroken boekjaren die eindigen op 31 maart respectievelijk 30 november. Indien in het navolgende wordt gesproken over het boekjaar 1993 dan wordt met betrekking tot genoemde ondernemingen het boekjaar 1993/ 94 respectievelijk 1992/93 bedoeld.

8 Zie Moliterno (1991, hoofdstuk 3 en appendix D) voor een analyse van de verschillen tussen NL GAAP en US GAAP losstaand van de verslaggeving volgens Form $20-\mathrm{F}$.

9 Medewerkers van de financieel-administratieve afdelingen van de in deze paragraaf besproken ondernemingen danken wij voor het commentaar op het onderdeel dat betrekking heeft op hun eigen onderneming

10 Uitgangspunt vormen de cijfers zoals gepresenteerd in de aansluitingsoverzichten van de Forms $20-F$ over de desbetreffende boekjaren. Het komt immers geregeld voor dat oorspronkelijk gepubliceerde cijfers in latere Forms 20-F voor vergelijkingsdoeleinden worden aangepast, bijvoorbeeld vanwege stelselwijzigingen.

11 Zie Vergoossen (1991, pp. 462-463) voor een bespreking van de kwantitatieve effecten van de in 1990 door AEGON doorgevoerde stelselwijzigingen.

12 Zie persbericht van KLM inzake de financiële resultaten over de eerste negen maanden van het boekjaar 1994/95 d.d 2 februari 1995, p. 2.

13 Voor de goede orde zij vermeld, dat deze handelwijze niet geheel in overeenstemming is met US GAAP. Volgens US GAAP moet voor hyperinflatielanden namelijk de rapporteringsvaluta als functionele valuta worden genomen. Deze afwijking heeft evenwel niet tot materiële verschillen geleid.

14 Behalve als jaarrapport ter voldoening aan de jaarlijkse deponeringsverplichting kan Form 20-F ook worden gebruikt als inschrijvingsdocument voor bij de SEC te registreren effecten. Het eerste Form 20-F van Ahold is als zodanig gebruikt.

15 Zie m.m. noot 14

16 Overigens zij vermeld dat deze handelwijze naar ons oordeel niet in de lijn ligt van de Nederlandse regelgeving; uit een oogpunt van gelijktijdige stelselmatigheid dienen stelselwijzigingen in beginsel met terugwerkende kracht te worden doorgevoerd. Volgens de regelgeving van het International Accounting Standards Committee echter was en is het niet met terugwerkende kracht doorvoeren van onderhavige stelselwijziging uitdrukkelijk toegestaan (zie de 'oude' International Accounting Standard 8 (alinea 15) respectievelijk de herziene International Accounting Standard 22 (alinea 79)).

17 Stelselwijzigingen die leiden tot de toepassing van US GAAP betekenen overigens niet per definitie dat de verschillen kleiner worden. De effecten van de aanpassingen die nodig zijn om het eigen vermogen en het nettoresultaat in overeenstemming te brengen met US GAAP kunnen elkaar namelijk voor een deel compenseren. 